Uşak Üniversitesi Sosyal Bilimler Dergisi

$2014,7 / 2$

\title{
4. Sınıf Seviyesinde Ekrandan ve Kâğıttan Okumanın Okuduğunu Anlama, Okuma Hızı ve Metne Karşı Geliştirilen Tutum Üzerindeki \\ Etkisi
}

Mustafa BAŞARAN*

\section{Özet}

Çalışmada, bir metni kâğıttan ve ekrandan okumanın, okuduğunu anlama, metne karşı geliştirilen tutum ve okuma hızı üzerinde bir etkisi olup olmadığının tespiti amaçlanmıştır. Bu amaç doğrultusunda, 2013-2014 eğitim öğretim yılında Kütahya ili Tavşanlı ilçe merkezinde bulunan özel ve devlet ilkokulların 4. sınıflarına devam eden öğrencilerin oluşturduğu çalışma evreninden, $46^{\prime}$ sı kız ve $68^{\prime}$ i erkek olmak üzere toplam 114 öğrenci örneklem olarak seçilmiştir. Araştırma sonucunda dördüncü sinıf öğrencilerinin hem hikâye edici hem de bilgi verici metinleri ekrandan veya kâğıttan okumalarının onların metni anlaması ve okuma hızları üzerinde manidar bir etkisi olmadığı ancak öğrencilerin hikâye edici metinleri ekrandan ziyade kâğıttan okumaktan daha çok hoşlandıkları sonucuna ulaşılmıştır.

Anahtar kelimeler: Ekrandan okuma, Kâğıttan Okuma, Okumaya Yönelik Tutum.

\section{Effect of Reading on Screen and Paper on Elementary School 4th Grade Students' Reading Comprehension Reading Speed and their Attitudes}

\begin{abstract}
Aim of this study is that to determine effect of reading from printed materials and screen on Elementary School 4th Grade Students' reading comprehension, reading speed and attitudes. For this purpose, in the 20132014 academic year, 46 females and 68 males, including a total of $1144^{\text {th }}$ glass students were selected as examples from study private and public schools that is located in the district of Kütahya Province Tavşanlı center. According the sturdy results, there is not meaningful impact reading both narrative and expository texts from screen or printed materials fourth-grade students' text comprehension and reading speed. But students are very interested reading narrative text printed material rather than on the screen.
\end{abstract}

"Yard. Doç Dr. Dumlupınar Üniversitesi, Eğitim Fakültesi, Türkçe Öğretmenliği Bölümü. 
Key words: On-Screen Reading, Reading from the Printed Page, Attitudes towards Reading.

\section{Giriş}

Teknolojinin gelişmesiyle birlikte bilgi miktarının da artması ve bilgi üretme ve yayma araçlarının değişmesi, bireyleri ister istemez ekrandaki yazıları okuma mecburiyetinde bırakmaktadır. Bireylerin ilgi veya uzmanlık alanıyla ilgili yılda 15-20 kitabın basıldığı yıllar çok geride kalmıştır. Kâğıttan okuma konusunda israr eden bireyler bile hangi kitabı okuyacaklarına, hangi makalenin çıktısını alacaklarına önce ekrandan okuyarak karar vermektedirler. Küçük yaştaki okurlar için bile birçok bilgiyi ekrandan okuyarak almak bir mecburiyet haline gelmiştir.

\section{Okuma ve Okuduğunu Anlama}

İlgili literatürde okumanın ne olduğuna ilişkin birçok tanımın yapıldığı görülmektedir. Geleneksel tanımlara göre okuma, yazılı sembolleri seslendirmektir (Oguzkan, 1987; Demirel, 1999). Ancak günümüzde okuma, “okuma hızı ve motivasyonel faktörlerden etkilenen; karmaşık bir hiyerarşik yapı oluşturan birtakım zihinsel, psikolojik, fizyolojik faktörler ve özellikler tarafından desteklenen; simgesel anlamlandırmaya ve görsel-işitsel-dilsel işlemlere dayalı anlam kurma becerisi olarak tanımlanmaktadır (Fuchs, Fuchs, Hosp ve Jenkins, 2009; Akyol, 2005; Dökmen, 1994; Aytaş, 2005; Gürses, 1996). Bu tanımdan hareketle okuma, sadece yazının anlaşılması ya da seslendirilmesi değil okuyan ile yazan arasında kurulan iletişim köprüsü ve bir anlam inşa etme süreci olarak anlaşılmalıdır. Böylesine karmaşık ve birçok değişkenden etkilenen okumanın, metnin hazır bulunduğu ortamdan (kâğıttan veya ekrandan) etkilenmemesi mümkün değildir.

\section{Ekrandan okuma}

Metinlerin neredeyse tamamının bilgisayarlar yardımıyla oluşturulduğu; basım anına kadar metin üzerindeki tüm değişikliklerin yine bilgisayarlarla yapıldığı; internet, akıllı telefon ve diğer iletişim araçlarındaki gelişme ve zihniyet değişimi ile birlikte, propaganda, eğlendirme veya bilgilendirme amaçlı hemen bütün yazılı iletilerin ekranlardan paylaşıldığı günümüzde, yazılı bir metni ekrandan okumak nerdeyse kaçınılmaz hale gelmiştir. Toplumsal ilişkiler artık teknoloji temelli olmak durumdadır: Bireyler birbirleriyle, devletle, diğer şirket veya kurumlarla iletişimini teknolojik araçlar kullanarak sağlamakta; bu durum da teknoloji ve ekran okuryazarlı̆̆ını bir mecburiyet haline getirmektedir (Güneş, 2010; Altun, 2003). Bu sebepten ekrandan okumanın, okuduğunu 
anlama ve okumayı etkileyen diğer motivasyonel faktörler üzerindeki etkileri, hem eğitim teknolojisi hem de okuma eğitimi uzmanlarının son yıllarda üzerinde sıklıkla çalıştığı konulardır. İlgili literatürde günümüz şartlarında ekrandan okumanın kaçınılmaz olduğuna dair bir görüş birliği bulunmaktadır ancak ekrandan okumanın avantajlı mı yoksa dezavantajlı $\mathrm{m}$ olduğu konusunda bir görüş birliğine henüz ulaşılamamıştır. Aslında her yeniliğin bazı avantajları ve dezavantajları olduğu gerçeğinden hareketle bu durumu normal karşılamak gerekir. Zaten ürünü geliştirme aşamasının temel hedefi avantajları çoğaltmak; dezavantajları en aza indirmektir. Ancak bu bölümde çalışmanın amacı gereği, bilgisayar ve ekran teknolojilerinin geliştirilmesi değil, metinleri ekrandan okumanın avantajları ve dezavantajları tartışılacaktır.

\section{Ekrandan Okumanın Avantajları}

Metinleri ekrandan okumanın pek çok avantajı bulunmaktadır. Bu avantajlar temelde ekonomiklik, okumayı ve okuduğunu anlamayı kolaylaştırma, metinle okurun etkileşimini arttırma ve metinlerarasılık olarak dört başlıkta incelenebilir. Ekrandan okuma, metinle okurun karşıllıklı etkileşiminin artırmaktadır. Örneğin, okur metinle ilgili pek çok notu hiç zorlanmadan (kes/kopyala/yapıştır) alabileceği gibi metin üzerinde de istediği kadar değişikliği hiç zorlanmadan yapabilecek; metni dilediği gibi maniple edebilecektir. Ayrıca metin içerisinde bulunan linklerle veya internet bağlantısı bulunan bir bilgisayarla metinde geçen bir durumla ilgili çok miktarda ekstra bilgiye kolayca ulaşabilecek hatta metnin yazarına istediği soruyu sorabilecektir. Böylelikle okur metinlerarası okuma da yapabilecektir. Okur metnin uzunluğu ne kadar olursa olsun metnin içinde istediği bilgiyi çok kolay ve çabuk bulabilecektir. Ayrıca okur isterse metinle ilgili olarak kendi görüşlerini diğer okurlarla paylaşabilecek; diğer okurların metin hakkındaki görüşlerini de yine aynı ortam üzerinden öğrenebilecektir. Öğrencilerin okul öğrenmelerini arttırmak için de ekrandan okumaları gerekmektedir. Günümüzde hemen her sınıf seviyesinde öğrenciler ekrandan okuyarak bilgi edinmek durumdadır. Hatta öğrencilere birçok ders kitabıyla beraber içinde elektronik metinlerin bulunduğu CD'ler verilmektedir (Dillon, 1992; Gürcan, 2005; Güneş, 2010; Altun, 2003; Duran ve Ertuğrul, 2012; Maden, 2012).

Basılı metinlerde alfabe ile birlikte resim, şekil ve grafikler kullanilabilmektedir. Ancak, ekrandan okumada uygun programlar kullanılarak metindeki içerik, resim, şekil ve grafiklere ek olarak, birçok yazı 
karakteri ve ekran fontu, ses, görüntü, sesli görüntü, animasyonlar ve sembollerle desteklenebilir (Dikmen, 2013; Çakmak ve Altun, 2008). Dolayısıyla elektronik ortamdaki metinler klasik metin tanımının dışına çıkmakta metinle bütünleşmiş halde sunulan diğer unsurlarla beraber sözlü, yazıll, görsel ve işitsel bir bilgi kaynağı haline dönüşmektedir (Landow, 1992). Bu yaşantı zenginliği hem öğrenilenlerin kalıcılığının ve okumaya ilişkin olumlu tutumların artmasını sağlar hem de okurun metni anlamasının kolaylaştırır. Unutulmamalıdır ki önemli olan basılı bir metni elektronik metne dönüştürmek değil bu metne kendini daha kolay ifade edebilmesi (daha kolay ve tam olarak anlaşılabilmesi) için yeni özellikler eklemektir.

Basılı kaynaklarla kıyaslandığında, elektronik metinlere, kaynaklara veya yayınlara hem ulaşmak hem de bu bilgileri saklamak daha kolay ve ucuzdur. Ayrıca elektronik olarak yayınlanan çok sayıda bilimsel ve güncel bilgiye uzun zaman beklemeden ulaşılabilir. Raporların, makalelerin veya benzeri metinlerin tamamı genellikle okurun işine yaramaz. Okur, elektronik metinleri kullanarak işine yarayacak kısmı bulup okuyabilir. Böylece kâğıt israfı da büyük ölçüde engellenebilir. Burada ekrandan okumanın dolaylı bir avantajı daha ortaya çıkmaktadır: Elektronik yayıncılık, yayın maliyetlerini düşürmekte; kitap iadesi ve satılamaması gibi sorunların neden olduğu maddi kayıpları en aza indirmekte; kitap depolama masrafları ve dağıtım giderlerini azaltmaktadır. Bu sayede yayıncılar yayın listesini daha geniş tutabilmekte ve yeni yazarlara daha fazla şans verebilme fırsatı yakalayabilmektedirler (Gürcan, 2004; Gönen ve Balat, 2002; Önder, 2011).

Rukancı ve Anameriç'e (2003) göre öğretmen, öğrenci ve okul öğrenmeleri bağlamında elektronik metinlerin birçok avantajı vardır. Örneğin, elektronik metinler kullanılarak, güncelliğini yitirmiş bilgiler kapsam dışı bırakılabilir. Ders kitaplarının güncellenmiş yeni baskılarını ve uyarlamalarını yıllarca beklemek yerine öğrenciler ve öğretmenler güncellenmiş materyalleri yayıncılar aracılığıyla anında indirilebilme olanağına sahip olabilir. e-kitaplar/elektronik metinlerin kullanılması öğrencileri kitap dolu ağır çantalardan kurtarır. Özellikle kâr amacı gütmeyen e-yayıncılar, herhangi bir anlaşmaya bağlı kalmadan yazarların kendi kitaplarını satmalarına izin verebilir, böylece öğrenciler daha çok yazarla tanışabilir. Elektronik metinler engelli öğrenciler için de büyük kolaylık sağlar. Örneğin konuşan kelime işlemciler ve bu araçlara uygun programlar ile veya punto ve yazı karakterleri değiştirilerek, görme engellilerin okuma problemi büyük oranda ortadan kaldırılabilir. Elektronik metinlere sözlük eklenebilir. Böylece öğrenciler okurken anlamını bilmedikleri bir kelimeyle karşılaştıklarında anında kelimenin anlamını 
bakıp öğrenebilirler. Öğretmen önemli kısımları istediği gibi belirginleştirebilir, kelimeler hakkında açılamalar yazabilir. Dizüstü bilgisayarlar ve e-kitap okuyucu cihazlar art alan aydınlatmasına sahiptir. Böylelikle öğrenci geceleri evinde veya yurtta kimseyi rahatsız etmeden (1şıkları açmadan ve sayfaları çevirmeden) ekrandan dilediği metni okuyabilir. Kütüphanelerde genellikle bir kaynaktan bir tane bulunmaktadır. $\mathrm{Bu}$ durum ödünç verme işleminde sıkıntılara yol açmaktadır. Aynı kitabı isteyen iki okurdan biri o kaynaktan yararlanamamaktadır. Elektronik ödünç verme bu sıkıntıları ortadan kaldırabilir.

\section{Ekrandan Okumanın Dezavantajları}

Ekrandan okumanın avantajları yanında bazı dezavantajları da bulunmaktadır. Bu dezavantajları, elektronik metinleri oluşturup, paylaşmanın, okumanın ve anlamanın zorluğu olarak sınıflandırmak mümkündür (Güneş, 2010; Dağtaş, 2013; Duran ve Ertuğrul, 2012; Maden, 2012). Elektronik metin endüstrisinde henüz uluslararası bir standart geliştirilememiştir. Bu durumda bireyler her an yeni bir formatta yazılmış metinlerle karşılaşabilmekte, bu metinleri okurken ve anlarken kimi zaman zorlanmakta veya bu metinleri okumayı öğrenmek için fazladan zaman harcamak zorunda kalmaktadırlar. Hatta uluslararası standartların oluşmaması yüzünden bireyler bazen, ellerindeki cihazların desteklemediği formatta metinlerle karşılaşmakta ve bu metinleri hiç açamamaktadır. Elektronik metinler eğer kopyala-yapıştır yöntemiyle oluşturulduysa genellikle hiçbir metinsellik ölçütünü karşılamamakta; trilyonlarca sayfa içinden gerçekten kaliteli metinleri bulmak da ayrı bir zorluk olarak bireylerin karşısına çıkmaktadır. Bu içeriklerin doğruluğu da indirildiği sitenin yöneticisinin vicdanına kalmaktadır. Okurların karşılaştığı diğer bir zorluk da elektronik metinlerin yalnız bilgisayar vb. elektronik bir ortamda kullanılabilmesidir. Bu cihazlara ulaşmak kimi zaman gerçekten zor olmaktadır. Bazen de yazılım ve donanımların bozulması söz konusu olmakta, bu durumda alınan servisin kalitesi ve hızı da hemen tüm kullanıcıların beklentisinin çok altında kalmaktadır. Diğer bir husus, kullanıcıların ve öğretmenlerin elektronik kitapları verimli kullanmasını sağlayan becerilere sahip olmamasıdır. Bu beceriler olmadan öğretmenler ve öğrencilerden verim elde etmeyi beklemek yanlış olur. Son olarak, elektronik yayınlara ilişkin telif hakları sorunlarının giderilememesi nedeniyle hala bu ürünlerin üretimi ve dağıtımı hâlâ tam anlamıyla güvence altına alınamamıştır. 
Günümüzde yüksek çözünürlüklü ekranlar kullanılmasına ve okunabilirlik için çok çeşitli zemin-yazı veya yazı karakterleri geliştirilmiş olmasına rağmen elektronik metinleri uzun süre (bir saatten uzun) okumak baş ağrısı ve göz yorgunluğuna neden olmaktadır (Herring, 2001, akt: Maden, 2012). Ekran yüzeyinin parlaması veya parıltılar olması; gözün seçerek okuması; metinlerin parça parça ekranda görülmesi sonucu zihnin bu bilgileri birleştirmeye çalışması; ekran karşısında düzgün oturmama vb. nedenler, ekrandan okumada gözü ve zihni yormakta, giderek genel bir yorgunluğa neden olmaktadır. Bu bağlamda değerlendirilebilecek diğer bir dezavantaj ise ekrandan okumanın kâğıttan okumaya göre daha yavaş olmasıdır (Dağtaş, 2013). Güneş'e (2010) göre ekrandan okuma hızını düşüren çeşitli faktörler vardır. Bu faktörler, dikey gidip gelen ekran metinlerinin okuyucunun göz hareketlerini etkilemesi; ekrandaki metnin parça parça olması (bu durum anlama düzeyi ve dolayısıyla okuyucunu ilerleme hızını düşürür); ekran okumanın bireye psikolojik baskı yapması ve ekranın gözü kâğıda göre daha fazla yorması olarak sıralanabilir.

Literatürde ekrandan okumanin anlamayı da olumsuz etkileyebileceğine dair görüşlere rastlanmaktadır (Güneş, 2010; Dağtaş, 2013; Duran ve Ertuğrul, 2012; Maden, 2012). Aslında ekrandan okuma, anlamayı doğrudan etkilemez ancak anlamayı doğrudan etkileyen değişkenler üzerinde etkili olabilir. Örneğin, ekrandan okuma yukarıda belirtildiği gibi gözü ve zihni daha fazla yorar; okuma hızını düşürür. Ekranda metin sayfalarının ancak bir parçası görüldüğü için bu durum okurun, metindeki başlık, alt başlık ve yan başlık ilişkisini izlemesine engel olabilir; metnin ana düşüncesini yakalamayı zorlaştırabilir ve gerektiğinde ileriye ve geriye doğru okuma yapmayı zorlaştırabilir. Ekrandan okuduğunu anlama için okurun e-okurluk, teknoloji okuryazarlığı, farklı anlama ve zihinde yapılandırma vb. becerilere sahip olması gerekir. Bu becerileri yeteri kadar gelişmemiş okurun okuduğunu anlama düzeyi de düşecektir. Ekrandan okumada alışkanlık sonucu genellikle metinler satır satır değil, göz gezdirilerek okumaktadır. Ekranda bulunan metinler sabit değil sürekli ve hareketli; somut değil soyut ve geçicidir. Bu durum elektronik metinlerin anlaşılmasını güçleştirmektedir. Ekranda bulunan renkli ve hareketli resim ve şekiller, sesler vb. okurun dikkatini dağıtabilmektedir. Son olarak elektronik metinlerde kullanılan farklı yazı karakterleri kelime tanıma işlemini yavaşlatabilmektedir.

\section{Araştırmanın Amacı}


Araştırmanın amacl; bir metni kâğıttan ve ekrandan okumanın, okuduğunu anlama, metne karşı geliştirilen tutum ve okuma hızı üzerinde bir etkisi olup olmadığını tespit etmektir.

\section{Yöntem}

$\mathrm{Bu}$ araştırma betimsel niteliktedir ve nicel bir araştırmadır. Araştırmanın yöntemi ise değişkenlerin bir kez ölçüldüğü ve diğer değişkenlere göre bir farklılık gösterip göstermediğinin belirlendiği kesitsel taramadir.

\section{Evren ve Örneklem}

Araştırmanın çalışma evrenini, 2013-2014 eğitim öğretim yılında Kütahya ili Tavşanlı ilçe merkezinde bulunan özel ve devlet ilkokulların 4. sınıfa devam eden öğrenciler oluşturmaktadır. Bu evrenden amaçlı örnekleme yöntemlerinden, kolay ulaşılabilir durum örneklemesi yöntemi kullanılarak, 46'sı (\%40.4) kız ve 68'i (\%59.6) erkek olmak üzere toplam 114 öğrenci örneklem olarak seçilmiştir.

\section{Ölçme Araçları}

Araştırmada, araştırmacı tarafından geliştirilen ve üç bölümden oluşan anket kullanılmıştır. Birinci bölümde, öğrencilerin demografik özelliklerini belirmek amacıyla hazırlanmış altı soru bulunmaktadır. İkinci bölümde ise öğrencilerin okumaya karşı geliştirdikleri tutumu ölçmek amacıyla Başaran (2007) tarafından geliştirilen likert tipi üçlü derecelendirme ölçeği yer almaktadır. Ölçek, "katılmıyorum", "kararsızım" ve "katılıyorum" seçeneklerinden oluşmaktadır. Verilen cevaplar olumlu ifadeler için "katılmıyorum"'dan "katılıyorum"'a 1'den 3'e doğru puanlar verilerek, olumsuz ifadeler için ise tam tersi bir puanlama ile kodlanmıştır. Ölçeğin yapı geçerliği için yapılan faktör analizinde, toplam varyansın \%39.97'sini açıklayan tek faktör ortaya çıkmış ve 13 maddenin tamamının faktör yükleri .30'dan fazla çıkmıştır. Ölçme aracının güvenirliğini sağlamak amacıyla yapılan testte Cronbach Alfa katsayısı .65 olarak bulunmuştur. 
Tablo 1. Okumaya Karşı Geliştirilen Tutum Ölçeği Faktör Yükleri

\begin{tabular}{cc}
\hline Madde & F1 \\
\hline Madde. 10 & .613 \\
\hline Madde. 8 & .590 \\
\hline Madde. 9 & .552 \\
\hline Madde. 11 & .500 \\
\hline Madde. 13 & .479 \\
\hline Madde. 1 & .474 \\
\hline Madde. 7 & .459 \\
\hline Madde. 3 & .424 \\
\hline Madde. 5 & .388 \\
\hline Madde. 6 & .371 \\
\hline Madde. 12 & .363 \\
\hline Madde. 2 & .327 \\
\hline Madde. 4 & .303 \\
\hline
\end{tabular}

Üçüncü bölümde ekrandan veya kâğıttan okumanın öğrencilerin metne karşı geliştirdikleri tutumları ve metni anlamaları üzerindeki etkisinin belirlenmesi amacıyla seçilen dört metin; bu metinlere karşı öğrencilerin tutumlarını belirlemek amacıyla hazırlanan tutum ölçeği ve anlama testleri yer almaktadır. Öğrencilerin okudukları metne karşı geliştirdikleri tutumu ölçmek amacıyla likert tipi üçlü derecelendirme ölçeği kullanılmıştır. Ölçek, "katılmıyorum", "kararsızım" ve "katılıyorum" seçeneklerinden oluşmaktadır. Verilen cevaplar, olumlu ifadeler için “katılmiyorum"'dan "katılıyorum"'a 1'den 3'e doğru puanlar verilerek, olumsuz ifadeler için ise tam tersi bir puanlama ile kodlanmıştır. Kapsam geçerliğinin sağlanması için uzman görüşü alınmıştır. Uygulama sonrası ölçeğin yapı geçerliği için yapılan faktör analizinde, toplam varyansın 46.35'ini açıklayan tek faktör ortaya çıkmıştır. Ölçme aracında bulunan 11 maddenin tamamının faktör yükleri $.30^{\prime}$ dan fazladır. Ölçme aracının güvenirliğini sağlamak amacıyla yapılan testte Cronbach Alfa katsayısı .86 olarak bulunmuştur.

Tablo 2. Metne Karşı Geliştirilen Tutum Ölçeği Faktör Yükleri

\begin{tabular}{ll}
\hline Madde & F 1 \\
\hline Madde. 11 & .836 \\
\hline Madde. 4 & .822 \\
\hline Madde. 8 & .786 \\
\hline Madde. 2 & .769 \\
\hline Madde. 3 & .749 \\
\hline Madde. 1 & .734 \\
\hline
\end{tabular}




\begin{tabular}{ll}
\hline Madde. 9 & .649 \\
\hline Madde. 7 & .644 \\
\hline Madde. 5 & .510 \\
\hline Madde. 10 & .403 \\
\hline Madde. 6 & .395 \\
\hline
\end{tabular}

Öğrencilerin okuduğunu anlama düzeylerini belirlemek için verilen her bir metinle ilgili dört seçenekli sekiz tane çoktan seçmeli soru sorulmuştur. Bu testlerin geçerlilik ve güvenilirlik çalışmaları toplam 120 dördüncü sınıf öğrencisinin bulunduğu bir grupta yapılmıştır. Öğrencilerin verdikleri cevaplardan doğru olanlar " 1 " yanlış olanlar " 0 " olarak puanlanmıştır. Daha sonra \%27'lik üst ve alt grupta bulunan öğrencilerin puanları alınmış ve testlerin geçerlilik ve güvenilirliği bu puanlar kullanılarak hesaplanmıştır.

Tablo 3. Anlama Testlerinin Ön Uygulama Sonucu Elde Edilen Madde Analizi Sonuçları

\begin{tabular}{lcccccc}
\hline Metin & $\mathbf{N}$ & $\begin{array}{c}\text { Soru } \\
\text { sayısı }\end{array}$ & $\mathbf{X}$ & $\mathbf{S}$ & $\mathbf{P}$ & Güvenilirlik \\
\hline Mantarlar & 120 & 8 & 4.29 & 1.41 & .53 & .79 \\
\hline Enerji Kaynakları & 120 & 8 & 3.51 & 1.68 & .43 & .74 \\
\hline Kasabanın Kahramanı & 120 & 8 & 3.85 & 1.64 & .48 & .70 \\
\hline Türkiye Haritası & 120 & 8 & 3.36 & 1.86 & .42 & .76 \\
\hline
\end{tabular}

Tablo 3'te görüleceği üzere uygulama yapılan öğrenciler ortalama olarak Mantarlar isimli metinden 4.49, Enerji Kaynakları isimli metinden 3.51, Kasabanın Kahramanı isimli metinden 3.85 ve Türkiye Haritası isimli metinden 3.36 puan almıştır. Tabloya göre testlerin tamamının ayırıcılık gücü indeksi $.40^{\prime} \tan$ ve güvenilirlik katsayıları da $.70^{\prime}$ ten yüksektir. Madde bazında yapılan analizlerde soruların madde güçlük indekslerinin .40 ile .68; madde ayırt edicilik indekslerinin ise .42 ile .62 arasında değiştiği görülmüş̧ür. $\mathrm{Bu}$ verilerden hareketle kullanılan testlerin güçlük değerlerinin orta seviyede ve ayırt edici olduğu; dolayısıyla ölçme amacını gerçekleştirecek yeterlilikte olduğu söylenebilir. 


\section{Uygulama}

Uygulamalar, kendilerine yeterli açılamalar yapılan sınıf öğretmenleri tarafından bilgisayar laboratuarı ve sınıf ortamında yapılmıştır. Uygulamalar günde iki ders saati olmak üzere toplam iki gün ve dört ders saati içerisinde gerçekleştirilmiştir. Uygulamada 18,5 inç büyüklügünde, 1360x768 çözünürlüğe sahip standart led monitörler kullanılmıştır. Ekrandan okunan bütün metinler Microsoft Word programı kullanılarak açılmıştır. Yazılar basılı kaynakta olduğu gibi 10 punto ve Times New Roman yazı karakterindedir. Ekran tam ekran olacak şekilde ayarlanmıştır.

Uygulamanın birinci gününde örnekleme alınan 114 öğrencinin tamamı, anketin birinci ve ikinci bölümünde yer alan sorularla üçüncü bölümünde yer alan ilk iki metinle ilgili tutum ölçeği ve anlama testini cevaplamıştır. Bu metinler (Mantarlar ve Enerji Kaynakları) gruplardaki öğrencilerin hem hikâye edici hem de bilgi verici metinleri okuma hızları, anlamaları ve metne karşı geliştirdikleri tutumlar açısından bir fark olup olmadığının tespiti amacıyla her iki gruba da basılı olarak verilmiştir. Uygulamanın ikinci gününde üçüncü ve dördüncü metinler (Kasabanın Kahramanı ve Türkiye Haritası) birinci gruba yine basılı olarak verilmiş ikinci gruptaki öğrenciler ise aynı metinleri ekrandan okumuştur. Öğrenciler metinleri okuduktan sonra okudukları metinle ilgili tutum ölçeğini ve anlama testini cevaplandırmışlardır.

Öğrencilerin okuma hızlarının tespiti için, öğrencilerin okumaya aynı anda başlaması sağlanmış ve bir dakika sonra öğrencilerin hangi kelimede kaldıklarını işaretlemeleri istenmiştir.

Çizelge 1. Araştırmada Kullanılan Metinler ve Uygulanma Biçimleri

\begin{tabular}{|l|l|l|l|}
\hline \multirow{2}{*}{$\begin{array}{c}\text { Uygulama } \\
\text { zamanı }\end{array}$} & \multicolumn{1}{|c|}{ Kullanılan Metin } & \multicolumn{2}{c|}{ Uygulanma biçimi } \\
\cline { 3 - 4 } & & Birinci grup & İkinci grup \\
& & $\mathbf{N = 6 2 ;} \% \mathbf{5 4 . 4 )}$ & $\mathbf{( N = 5 2 ; ~ \% 4 5 . 6 )}$ \\
\hline Birinci gün & Mantarlar & Basılı & Basılı \\
& (Hikâye edici metin) & & \\
\cline { 2 - 4 } & Enerji Kaynakları & Basılı & Basılı \\
& (Bilgi verici metin) & & \\
\hline
\end{tabular}




\begin{tabular}{|l|l|l|l|}
\hline İkinci gün & $\begin{array}{l}\text { Kasabanın Kahramanı } \\
\text { (Hikâye edici metin) }\end{array}$ & Basılı & Ekrandan \\
\cline { 2 - 4 } & $\begin{array}{l}\text { Türkiye Haritası } \\
\text { (Bilgi verici metin) }\end{array}$ & Basılı & Ekrandan \\
& & & \\
\hline
\end{tabular}

\section{Bulgular ve Yorum}

Bu bölümde araştırma sonucu elde edilen bulgular, tablolar halinde verilmiş ve yorumlanmıştır.

Tablo 4. Her İki Gruba da Basılı Şekilde Verilen Metinlerle İlgili Olarak Öğrencilerin Okuma Hızları ile Tutum ve Anlama Puanlarının Karşılaştırılması

\begin{tabular}{|c|c|c|c|c|c|c|}
\hline \multirow[t]{2}{*}{$\begin{array}{l}\text { Değişkenler } \\
\text { Sd }=112\end{array}$} & \multicolumn{2}{|c|}{$\begin{array}{l}\text { I. Grup (Basılı } \\
\text { materyali okuyan } \\
\text { gurup) } \mathrm{N}=62\end{array}$} & \multicolumn{2}{|c|}{$\begin{array}{c}\text { II. Grup } \\
\text { (Ekrandan } \\
\text { okuyan gurup) } \\
\mathrm{N}=52\end{array}$} & \multirow[t]{2}{*}{$t$} & \multirow[t]{2}{*}{$\mathrm{p}$} \\
\hline & $\bar{X}$ & $S$ & $\bar{X}$ & $S$ & & \\
\hline $\begin{array}{l}\text { Okumaya karşı geliştirilen } \\
\text { tutum }\end{array}$ & 35.35 & 3.33 & 35.51 & 3.26 & .265 & .792 \\
\hline $\begin{array}{l}\text { Hikâye edici metne karşı } \\
\text { geliştirilen tutum }\end{array}$ & 30.20 & 2.94 & 30.75 & 1.98 & 1.125 & .263 \\
\hline $\begin{array}{l}\text { Bilgi verici metne karşı } \\
\text { geliştirilen tutum }\end{array}$ & 26.77 & 5.97 & 26.03 & 6.54 & .627 & .532 \\
\hline Hikâye edici metni anlama & 4.33 & 1.30 & 4.67 & 1.14 & 1.438 & .153 \\
\hline Bilgi verici metni anlama & 3.27 & 1.33 & 3.23 & 1.33 & .173 & .863 \\
\hline $\begin{array}{l}\text { Hikâye edici metni okuma } \\
\text { hızı }\end{array}$ & 129.90 & 50.13 & 123.30 & 38.28 & .768 & .444 \\
\hline $\begin{array}{l}\text { Bilgi verici metni okuma } \\
\text { hızı }\end{array}$ & 117.45 & 40.13 & 124.12 & 45.46 & .824 & .412 \\
\hline
\end{tabular}


Tablo 4'te iki gruptaki öğrencilerin kâğıttan okudukları hikâye edici ve bilgi verici metinleri anlamaları, metne karşı geliştirdikleri tutumları, okuma hızları ve okumaya ilişkin tutumları arasında manidar bir fark olup olmadığını tespit etmek amacıyla yapılan $t$ testi sonuçları görülmektedir. Tablo incelendiğinde her iki gruptaki öğrencilerin de okumaya ilişkin tutumları, kâğıttan okudukları hikâye edici ve bilgi verici metinleri anlamaları, okuma hızları ve bu metinlere karşı geliştirdikleri tutumları arasında manidar bir fark olmadığı görülmektedir ( $\mathrm{p}>.05)$.

Tablo 5. Öğrencilerin Farklı Şekillerde (Kâğıttan ve Ekrandan) Verilen Metinlere İlişkin Tutum, Anlama ve Okuma Hızı Puanlarının Karşılaştırılması

\begin{tabular}{|c|c|c|c|c|c|c|}
\hline \multirow[t]{3}{*}{$\begin{array}{l}\text { Değişkenler } \\
\text { Sd=112 }\end{array}$} & \multirow{2}{*}{\multicolumn{2}{|c|}{$\begin{array}{l}\text { (Kâğıttan) } \\
\text { okuyan gurup) } \\
\text { N=62 }\end{array}$}} & \multicolumn{2}{|c|}{$\begin{array}{c}\text { II. Grup } \\
\text { (Ekrandan } \\
\text { okuyan gurup) } \\
\mathrm{N}=52\end{array}$} & \multirow[t]{3}{*}{$t$} & \multirow[t]{3}{*}{$\mathrm{p}$} \\
\hline & & & & & & \\
\hline & $\mathbf{X}$ & $S$ & $X$ & $S$ & & \\
\hline $\begin{array}{l}\text { Hikâye edici metne karşı } \\
\text { geliştirilen tutum }\end{array}$ & 30.79 & 2.66 & 27.67 & 5.63 & 3.871 & .000 \\
\hline $\begin{array}{l}\text { Bilgi verici metne karş1 } \\
\text { geliştirilen tutum }\end{array}$ & 28.96 & 5.14 & 27.86 & 4.93 & 1.161 & .248 \\
\hline Hikâye edici metni anlama & 5.08 & 1.34 & 4.76 & 1.52 & 1.156 & .250 \\
\hline Bilgi verici metni anlama & 3.27 & 1.33 & 3.23 & 1.33 & .173 & .863 \\
\hline $\begin{array}{l}\text { Hikâye edici metni okuma } \\
\text { hızı }\end{array}$ & 131.19 & 47.71 & 122.63 & 37.81 & 1.047 & .297 \\
\hline $\begin{array}{l}\text { Bilgi verici metni okuma } \\
\text { hızı }\end{array}$ & 117.45 & 40.13 & 124.92 & 42.12 & .968 & .335 \\
\hline
\end{tabular}

Tablo 5. incelendiğinde, hikâye edici metinleri kâğıttan okuyan öğrencilerle, ekrandan okuyan öğrenciler arasında, metne karşı geliştirilen 
tutum açısından anlamlı bir fark olduğu görülmektedir $(p<.05)$. Hikâye edici metni kâğıttan okuyan öğrencilerin metne karşı geliştirilen tutum ölçeğinden ortalama 30.79, ekrandan okuyan öğrencilerin ise 27.67 puan aldıkları görülmektedir. Bu bulgulardan hareketle öğrencilerin hikâye edici metinleri kâğıttan okumaktan daha çok hoşlandıkları, ancak bilgi verici metinlerin kâğıttan veya ekrandan okunmasının metne karşı geliştirilen tutum üzerinde etkili olmadığı söylenebilir. Ayrıca hem bilgi verici hem de hikaye edici metinleri ekrandan ya da kâğıttan okumanın, okuma hızı ve anlama üzerinde manidar bir etkisi bulunmamaktadır. 
Tablo 6. Öğrencilerin Farklı Şekillerde (Kâğıttan ve Ekrandan) Verilen Metinlere İlişkin Tutum, Anlama ve Okuma Hızı Puanlarının Cinsiyet Değişkeni Açısından Karşılaştırılması

Tablo 6'da görüleceği üzere, cinsiyet değişkeninin, ekrandan ya da

\begin{tabular}{|c|c|c|c|c|c|c|c|}
\hline Değişken & $\begin{array}{l}\text { Varyansın } \\
\text { kaynağı }\end{array}$ & K.T. & Sd. & K.O. & $\mathbf{F}$ & $p$ & $\begin{array}{c}\text { Fark } \\
(*)\end{array}$ \\
\hline \multirow{3}{*}{$\begin{array}{l}\text { Hikâye } \\
\text { karşı } \\
\text { tutum }\end{array}$} & $\begin{array}{l}\text { Gruplar } \\
\text { arası }\end{array}$ & 314.66 & 3 & 104.88 & \multirow{3}{*}{3.729} & \multirow{3}{*}{.151} & - \\
\hline & Gruplar içi & 2013.86 & 110 & 18.30 & & & \\
\hline & Toplam & 2328.52 & 113 & & & & \\
\hline \multirow{3}{*}{$\begin{array}{lr}\text { Bilgi } & \text { verici } \text { metne } \\
\text { karşı } & \text { geliştirilen } \\
\text { tutum } & \end{array}$} & $\begin{array}{l}\text { Gruplar } \\
\text { arası }\end{array}$ & 90.01 & 3 & 30.00 & \multirow{3}{*}{1.180} & \multirow{3}{*}{.321} & - \\
\hline & Gruplar içi & 2798.34 & 110 & 25.43 & & & \\
\hline & Toplam & 2888.36 & 113 & & & & \\
\hline \multirow[t]{3}{*}{$\begin{array}{l}\text { Hikâye edici metni } \\
\text { anlama }\end{array}$} & $\begin{array}{l}\text { Gruplar } \\
\text { arası }\end{array}$ & 6.68 & 3 & 2.22 & \multirow{3}{*}{1.085} & \multirow{3}{*}{.358} & - \\
\hline & Gruplar içi & 225.88 & 110 & 2.05 & & & \\
\hline & Toplam & 232.57 & 113 & & & & \\
\hline \multirow[t]{3}{*}{$\begin{array}{l}\text { Bilgi verici metni } \\
\text { anlama }\end{array}$} & $\begin{array}{l}\text { Gruplar } \\
\text { arası }\end{array}$ & 11.70 & 3 & 3.90 & \multirow{3}{*}{1.636} & \multirow{3}{*}{.185} & - \\
\hline & Gruplar içi & 262.23 & 110 & 2.38 & & & \\
\hline & Toplam & 273.93 & 113 & & & & \\
\hline \multirow[t]{3}{*}{$\begin{array}{l}\text { Hikâye edici metni } \\
\text { okuma hızı }\end{array}$} & $\begin{array}{l}\text { Gruplar } \\
\text { arası }\end{array}$ & 6991.39 & 3 & 2330.46 & \multirow{3}{*}{1.239} & \multirow{3}{*}{.299} & - \\
\hline & Gruplar içi & 20685.05 & 110 & 1880.47 & & & \\
\hline & Toplam & 21343.44 & 113 & & & & \\
\hline \multirow[t]{3}{*}{$\begin{array}{l}\text { Bilgi verici metni } \\
\text { okuma hızı }\end{array}$} & $\begin{array}{l}\text { Gruplar } \\
\text { arası }\end{array}$ & 3721.62 & 3 & 1240.54 & \multirow{3}{*}{.731} & \multirow{3}{*}{.535} & - \\
\hline & Gruplar içi & 18658.12 & 110 & 1696.25 & & & \\
\hline & Toplam & 19039.75 & 113 & & & & \\
\hline
\end{tabular}

*1. Kâğıttan okuyan kız; 2. Kâğıttan okuyan erkek; 3. Ekrandan okuyan kız; 4. Ekrandan okuyan erkek 
basılı materyalden okunduğunda hem hikâye edici hem de bilgi verici metinleri anlama, okuma hızı ve bu metinlere ilişkin geliştirilen tutum üzerinde etkili olmadığı görülmektedir ( $\mathrm{p}>.05)$. Bu bulgular, hem basılı materyalden hem de ekrandan okurken metni anlama, okuma hizı ve metne karşı geliştirilen tutum üzerinde cinsiyet değişkeninin manidar bir etkisinin olmadığı şeklinde yorumlanabilir.

Tablo 7. Öğrencilerin Farklı Şekillerde (Kâğıttan ve Ekrandan) Verilen Metinlere İlişkin Tutum, Anlama ve Okuma Hızı Puanlarının Okumaya Karşı Geliştirilen Tutum Değişkeni Açısından Karşılaştırılması

\begin{tabular}{|c|c|c|c|c|c|c|c|}
\hline Değişkenler & Grup* & $\mathbf{N}$ & $\begin{array}{l}\text { Ortalama } \\
\text { Ranj }\end{array}$ & sd & KWT & p & $\begin{array}{c}\text { Fark } \\
(\mathrm{MWU}) \\
\end{array}$ \\
\hline Hikâye edici metne & 1 & 15 & 64.00 & 3 & 5.565 & .142 & - \\
\hline \multirow{3}{*}{ karşı geliştirilen tutum } & 2 & 47 & 65.59 & & & & \\
\hline & 3 & 11 & 34.77 & & & & \\
\hline & 4 & 41 & 51.95 & & & & \\
\hline \multirow{4}{*}{$\begin{array}{l}\text { Bilgi verici metne karşı } \\
\text { geliştirilen tutum }\end{array}$} & 1 & 15 & 52.87 & 3 & 5.372 & .147 & - \\
\hline & 2 & 47 & 65.45 & & & & \\
\hline & 3 & 11 & 44.59 & & & & \\
\hline & 4 & 41 & 53.55 & & & & \\
\hline \multirow{4}{*}{$\begin{array}{l}\text { Hikâye edici metni } \\
\text { anlama }\end{array}$} & 1 & 15 & 57.17 & 3 & 2.071 & .558 & - \\
\hline & 2 & 47 & 62.46 & & & & \\
\hline & 3 & 11 & 52.55 & & & & \\
\hline & 4 & 41 & 53.27 & & & & \\
\hline \multirow{4}{*}{$\begin{array}{lll}\text { Bilgi } & \text { verici } & \text { metni } \\
\text { anlama } & & \end{array}$} & 1 & 15 & 59.90 & 3 & 3.922 & .270 & - \\
\hline & 2 & 47 & 63.49 & & & & \\
\hline & 3 & 11 & 46.50 & & & & \\
\hline & 4 & 41 & 52.71 & & & & \\
\hline \multirow{4}{*}{$\begin{array}{l}\text { Hikâye edici metni } \\
\text { okuma hızı }\end{array}$} & 1 & 15 & 43.53 & 3 & 10.983 & .012 & $3-2$ \\
\hline & 2 & 47 & 63.71 & & & & $3-4$ \\
\hline & 3 & 11 & 33.32 & & & & \\
\hline & 4 & 41 & 61.98 & & & & \\
\hline \multirow{4}{*}{$\begin{array}{l}\text { Bilgi verici metni okuma } \\
\text { h1zı }\end{array}$} & 1 & 15 & 34.30 & 3 & 9.773 & .021 & $1-2$ \\
\hline & 2 & 47 & 60.65 & & & & $1-4$ \\
\hline & 3 & 11 & 51.45 & & & & \\
\hline & 4 & 41 & 64.00 & & & & \\
\hline \multicolumn{8}{|c|}{$\begin{array}{l}\text { *1. Okumaya karşı olumlu tutumu düşük, kâğıttan okuyan; } 2 \text {. Okumaya karşı olumlu } \\
\text { tutumu yüksek, kâğıttan okuyan; 3. Okumaya karşı olumlu tutumu düşük ekrandan } \\
\text { okuyan; } 4 \text {. Okumaya karşı olumlu tutumu yüksek ekrandan okuyan. }\end{array}$} \\
\hline
\end{tabular}

Tablo 7'de metni ekrandan ve kâğıttan okumanın, okumaya karşı geliştirdiği olumlu tutumu yüksek ve düşük öğrencilerin, okuduğu metne karşı geliştirdikleri tutum, metni okuma hızları ve anlamaları üzerindeki 
etkisi görülmektedir. Yapılan Kuriskal Wallis Testi sonuçlarına göre okumaya karşı geliştirilen tutum değişkeni, hikâye edici ve bilgi verici metinleri okuma hızı üzerinde etkili olmakta; diğer değişkenler üzerinde ise anlamlı bir farklılık yaratmamaktadır [hikâye edici metni okuma hızı için KWT $=10.983$ ve $\mathrm{p}<.05$ ve bilgi verici metni okuma hızı içinse KWT=9.773 ve $\mathrm{p}>$.05]. Bu sonucun hangi gruplar arasındaki farktan kaynaklandığının tespiti için yapılan Mann Whitney U Testi sonuçlarına göre farklılık, hikaye edici metni okuma hızı değişkeni için, okumaya karşı olumlu tutumu düşük ekrandan okuyan öğrencilerle okumaya karşı olumlu tutumu yüksek kâğıttan okuyan ve okumaya karşı olumlu tutumu yüksek ekrandan okuyan öğrenciler arasında; bilgi verici metni okuma hızı değişkeni için ise okumaya karşı olumlu tutumu düşük kâğıttan okuyan öğrencilerle, okumaya karşı olumlu tutumu yüksek kâğıttan okuyan ve okumaya karşı olumlu tutumu yüksek ekrandan okuyan öğrenciler arasındadır. Bu bulguları okumaya karşı olumlu tutumları düşük öğrencilerin, ekrandan okurken hem hikaye edici hem de bilgi verici metinleri okuma hızlarının düştüğü şeklinde yorumlamak mümkündür. Bu durumun sebebi okumaya karşı olumlu tutumları düşük öğrencilerin okumaktan çok ekrandaki diğer uyarıcılarla ilgilenmesi olabilir.

Tablo 8. Öğrencilerin Farklı Şekillerde (Kâğıttan ve Ekrandan) Verilen Metinlere İlişkin Tutum, Anlama ve Okuma Hızı Puanlarının Haftada Okudukları Ortalama Kitap Sayısı Değişkeni Açısından Karşılaştırılması

\begin{tabular}{|c|c|c|c|c|c|c|c|}
\hline Değişkenler & Grup* & $\mathbf{N}$ & $\begin{array}{c}\text { Ortalama } \\
\text { Ranj }\end{array}$ & sd & KWT & p & $\begin{array}{c}\text { Fark } \\
\text { (MWU) }\end{array}$ \\
\hline Hikâye edici metne & 1 & 14 & 51.71 & 5 & 9.984 & .061 & \multirow{6}{*}{-} \\
\hline \multirow[t]{5}{*}{ karş1 geliştirilen tutum } & 2 & 28 & 67.55 & & & & \\
\hline & 3 & 20 & 71.35 & & & & \\
\hline & 4 & 16 & 49.81 & & & & \\
\hline & 5 & 24 & 45.44 & & & & \\
\hline & 6 & 12 & 52.08 & & & & \\
\hline \multirow{6}{*}{$\begin{array}{l}\text { Bilgi verici metne karşı } \\
\text { geliştirilen tutum }\end{array}$} & 1 & 14 & 68.39 & \multirow[t]{6}{*}{5} & \multirow[t]{6}{*}{4.025} & \multirow[t]{6}{*}{.546} & \multirow[t]{6}{*}{-} \\
\hline & 2 & 28 & 62.27 & & & & \\
\hline & 3 & 20 & 58.40 & & & & \\
\hline & 4 & 16 & 48.72 & & & & \\
\hline & 5 & 24 & 52.33 & & & & \\
\hline & 6 & 12 & 54.21 & & & & \\
\hline \multirow{4}{*}{$\begin{array}{l}\text { Hikâye } \\
\text { anlama }\end{array}$} & 1 & 14 & 60.21 & \multirow[t]{4}{*}{5} & \multirow[t]{4}{*}{9.784} & \multirow[t]{4}{*}{.082} & \multirow[t]{4}{*}{-} \\
\hline & 2 & 28 & 67.98 & & & & \\
\hline & 3 & 20 & 52.33 & & & & \\
\hline & 4 & 16 & 38.03 & & & & \\
\hline
\end{tabular}




\begin{tabular}{|c|c|c|c|c|c|c|c|}
\hline & 5 & 24 & 58.02 & & & & \\
\hline & 6 & 12 & 63.42 & & & & \\
\hline \multirow{6}{*}{$\begin{array}{ll}\text { Bilgi } & \text { verici } \\
\text { anlama }\end{array}$} & 1 & 14 & 59.39 & \multirow[t]{6}{*}{5} & \multirow[t]{6}{*}{7.181} & \multirow[t]{6}{*}{208} & \multirow[t]{6}{*}{ - } \\
\hline & 2 & 28 & 59.59 & & & & \\
\hline & 3 & 20 & 69.13 & & & & \\
\hline & 4 & 16 & 44.09 & & & & \\
\hline & 5 & 24 & 50.29 & & & & \\
\hline & 6 & 12 & 63.33 & & & & \\
\hline \multirow{6}{*}{$\begin{array}{l}\begin{array}{l}\text { Hikâye edici metni } \\
\text { okuma hızı }\end{array}\end{array}$} & 1 & 14 & 59.82 & \multirow[t]{6}{*}{5} & \multirow[t]{6}{*}{1.965} & \multirow[t]{6}{*}{.854} & \multirow[t]{6}{*}{ - } \\
\hline & 2 & 28 & 56.82 & & & & \\
\hline & 3 & 20 & 60.95 & & & & \\
\hline & 4 & 16 & 47.59 & & & & \\
\hline & 5 & 24 & 58.50 & & & & \\
\hline & 6 & 12 & 61.83 & & & & \\
\hline \multirow{6}{*}{$\begin{array}{l}\text { Bilgi verici metni okuma } \\
\text { hızı }\end{array}$} & 1 & 14 & 56.96 & \multirow[t]{6}{*}{5} & \multirow[t]{6}{*}{2.586} & \multirow[t]{6}{*}{.763} & \multirow[t]{6}{*}{ - } \\
\hline & 2 & 28 & 50.73 & & & & \\
\hline & 3 & 20 & 57.35 & & & & \\
\hline & 4 & 16 & 55.59 & & & & \\
\hline & 5 & 24 & 63.69 & & & & \\
\hline & 6 & 12 & 64.33 & & & & \\
\hline
\end{tabular}

*1. Haftada 49 sayfaya kadar okuyan kâğıttan okuyan; 2. Haftada 50-99 sayfa okuyan kâğıttan okuyan; 3 . Haftada +100 sayfa okuyan kâğıttan okuyan; 4 . Haftada 49 sayfaya kadar okuyan ekrandan okuyan. 5. Haftada 50-99 sayfa okuyan ekrandan okuyan; 6 . Haftada +100 sayfa okuyan ekrandan okuyan.

Tablo 8 incelendiğinde haftada okunan ortalama kitap miktarı değişkeninin, hem hikâye edici ve hem de bilgi verici metinleri kâğıttan veya ekrandan okuyan öğrencilerin okuma hızı, metne karşı geliştirdikleri tutum ve metni anlamaları üzerinde manidar bir etkisinin olmadığ 1 görülmektedir ( $p>05)$. Bu bulgu, metni hem kâğıttan hem de ekrandan okuma söz konusu olduğunda, kitap okuma miktarı değişkeninin, metne karşı geliştirilen tutum, metni anlama ve okuma hızı üzerinde manidar bir etkisinin olmadığı şeklinde yorumlanabilir.

\section{Tartışma, Sonuç ve Öneriler}

Araştırma sonucunda dördüncü sınıf öğrencilerinin görece kısa olan hem hikâye edici hem de bilgi verici metinleri ekrandan veya kâğıttan okumalarının onların metni anlaması ve okuma hızları üzerinde manidar bir etkisinin olmadığı sonucuna ulaşılmıştır. Ancak öğrenciler, hikâye edici metinleri kâğıttan okumaktan daha çok hoşlanmaktadırlar. Bilgi verici metinlerin ise ekrandan veya kâğıttan okunması metne karşı geliştirilen tutum üzerinde manidar bir fark yaratmamaktadır. Bu bulgu Yaman ve Dağtaş'in (2013) sekizinci sınıf; Baştuğ ve Keskin'in (2012) beşinci sınıf 
seviyesinde yaptıkları araştırmaların bulgularıyla çelişiyor görülmektedir. Yaman ve Dağtaş'a göre ekrandan okuma öğrencilerin okumaya karşı geliştirdikleri olumlu tutumu yükseltmekte; Baştuğ ve Keskin'e göre ise kâ̆ğttan okuma hem okumaya ilişkin olumlu tutumu hem anlamayı hem de okuma hızını pozitif yönde manidar bir şekilde arttırmaktadır. Bu çelişki, bahsi geçen araştırmalarda kullanılan metinlerin uzunluğu ve sınıf seviyesi ile bu araştırmada kullanılan metinlerin uzunluğu ve sınıf seviyesinin farklı olmasından kaynaklanabilir. Zira sekizinci sınıf öğrencileri bilgisayarları ve elektronik metinleri daha ustalıkla ve amaçlarına daha uygun olarak kullanma becerisine sahiptir. Ayrıca metinler uzadıkça ekrandan veya kâğıttan okumanın tutum üzerindeki etkisi değişebilir. Nitekim, Quéré, Leguay, Robert, Mesnager, Jarry (1997) ve Baccino (1996) (Akt; Güneş, 2010) yaptıkları araştırmalarda, kısa metinleri ekrandan okumanın kolay ancak uzun metinleri okumanın ve metinler arası karşılaştırma yapmanın oldukça zor olduğu sonucuna ulaşmışlardır.

Cinsiyet değişkeni açısından bakıldığında ister kâğıttan isterse ekrandan okunsun kız ve erkek öğrencilerin metni anlama, metne karşı geliştirilen tutum ve okuma hızları arasında manidar bir farklılık bulunmamaktadır.

Öğrencilerin bir haftada okudukları ortalama kitap miktarı açısından bakıldığında, ekrandan veya kâğıttan okumanın, metne karşı geliştirilen tutum, anlama ve okuma hızı üzerinde manidar bir etkisi yoktur. Öğrencilerin okumaya karşı geliştirdikleri tutumlar açısından bakıldığında, okumaya karşı düşük seviyede olumlu tutum geliştiren öğrenciler hem hikâye edici hem de bilgi verici metinleri ekrandan daha yavaş okumaktadırlar.

Ülkemizde veliler, öğretmenler, akademisyenler ve eğitim yöneticileri ekrandan veya kâğıttan okuma hakkında olumlu/olumsuz birçok görüş ileri sürmektedirler. Ancak bu görüşler kişisel tecrübe, alg1 ve alışkanlıkların sonucudur. Örneğin Duran ve Ertuğrul (2012) yaptıkları araştırmada öğretmenlerin ekrandan okumayı tercih etmemelerinde alışkanlıkların önemli bir rol oynadığı sonucuna ulaşmışlardır. Ekrandan okuma için olumsuz görüşlerin diğer bir kaynağı da ekranların parlaklığı ve titreşimi dolayısıyla gözün daha fazla yorulacağına ilişkin inançtır. Dağtaş (2013) ve Maden'in (2012) yaptıkları araştırmalarda çıkan sonuçlar da bu tezi doğrulamaktadır. Bu araştırma sonuçlarına göre öğretmen adaylarına göre ekrandan okumanın en olumsuz tarafı "ekrandan okumanın, göz rahatsızlıklarına ve diğer bazı rahatsızlıklara neden olabilmesidir". Ancak ekran teknolojisindeki gelişmelerle birlikte ekrandan okumanın bu dezavantajının oldukça azaldığı söylenebilir. 
Çalışmanın sonuçlarından da anlaşılacağı üzere ilköğretim dördüncü sınıf öğrencilerinin anlama, okuma hızı ve metne karşı geliştirdikleri tutumları üzerinde ekrandan veya kâğıttan okumanın genel olarak manidar bir etkisi bulunmamaktadır. Günümüzde masaüstü, dizüstü veya tablet bilgisayar teknolojisindeki gelişmeler bu araçlara daha kolay ve ucuza ulaşma olanağı sağlamaktadır. Ayrıca bu araçları kullanarak okuma, çok miktardaki bilgiye daha ucuza ulaşabilme ve bu bilgileri kolayca taşıyabilme, bilgiye daha kısa sürede ulaşabilme, bilgiler üzerinde değişiklilikler yapabilme, okuduğu metinle ilgili olarak başka okurlarla ve yazarla iletişim kurabilme vb. birçok avantaj sağlamaktadır. O halde ekrandan okumanın teşvik edilmesi ve ekrandan okuma becerilerinin öğrencilere erken sınıflarda kazandırılması gerektiği söylenebilir. Öğrencilerin fiziksel ve bilişsel gelişim özelliklerine uygun ekranların ve yazılımların seçilmesi ve geliştirilmesine önem verilmelidir. Hangi sınıf seviyesinde çalıştığına ve kıdemine bakılmaksızın öğretmenlerin ekran okuma ve ekranı verimli kullanma konusunda becerileri meslek içi eğitimlerle iyileştirilmelidir.

İlköğretim seviyesinde öğretmenler, sınıflarında özellikle hikâye edici metinlerin, şiirlerin veya uzun metinlerin okunması söz konusu olduğunda ekrandan okuma yerine kâğıttan okumayı tercih etmelidir. Ayrıca okumaya karşı olumlu tutumları düşük öğrencilerle yapılan okuma etkinliklerinde de öğretmenler basılı materyalleri kullanmalıdır.

Teknolojik gelişmelerle birlikte günlük hayatta ve sınıflarda metinler kaçınılmaz olarak dijital ortamda oluşturulmakta ve ekrandan okunmaktadır. Bu sebepten ekrandan okuma üzerinde daha çok bilimsel çalışma yapılmalıdır. Örneğin ekrandan okumada metnin uzunluğu, sınıf seviyesi, kullanılan teknolojik araç, kullanılan program ve öğrencinin teknoloji okuryazarlığının, öğrencilerin metni anlaması, okuma hızı ve metne karşı geliştirdikleri tutumlar üzerindeki etkileri araştırılabilir.

\section{Kaynakça}

Akyol, H. (2005). Yeni Programa Uygun Türkçe İlk Okuma Yazma Öğretimi. Ankara: PegemA Yayıncılık.

Altun, A. (2003). E-okuryazarlık. Millî Eğitim Dergisi, S.158.

Aytaş, G. (2005). Okuma Eğitimi. Türk Ĕ̆itim Bilimleri Dergisi, 3 (4), 461-470. 
Başaran, M. (2007). İlköğretim Beşinci Sınıf Öğrencilerinin Hikâye Edici Metinlere İlişkin Tercihleri. Yayınlanmamış Doktora Tezi, Gazi Üniversitesi Gazi Eğitim Bilimleri Enstitüsü, Ankara

Baştuğ, M. ve Keskin, H. K. (2012) Okuma Becerilerinin Okuma Ortamı Açısından Karşılaştırılması: Ekran mı kâğı̆ mı? Atatürk Üniversitesi Sosyal Bilimler Enstitüsü Dergisi 16 (3), 73-83.

Çakmak, E. ve Altun, A. (2008). İlköğretim Öğrencilerinin Hipermetinsel Okuma Süreçlerinin İncelenmesi. Hacettepe Üniversitesi Eğitim Fakültesi Dergisi, S: 34, 63-74.

Dağtaş, A. (2013). Öğretmenlerin Basılı Sayfa ve Ekrandan Okuma Tercihleri İle Eğitimde Elektronik Metin Kullanımına Yönelik Görüşleri. Turkish Studies. 8 (3), 137-161.

Demirel, Ö. (1999). Türkçe Öğretimi. Ankara: PegemA Yayıncılık.

Dikmen, Ü. (2013). Ekran Fontlarının Kullanılabilirliğe Etkisi. İDİL, 2 (6), 306-324.

Dillon, A. (1992). Reading From Paper Versus Screens: A Critical Review Of The Empirical Literature. Ergonomics, 35 (10), 1297-1326.

Dökmen, Ü. (1994). Okuma Becerisi, İlgisi ve Alışkanlığı Üzerine PsikoSosyal Bir Araştırma. İstanbul: Milli Eğitim Basımevi.

Duran E. ve Ertuğrul, B. (2012) İlköğretim Sınıf Öğretmenlerinin Elektronik Ders Kitaplarına Yönelik Görüşleri. Türk Eğitim Bilimleri Dergisi. $10(2), 347-365$.

Fuchs, L. S., Fuchs D., Hosp M. K. ve Jenkins J. R. (2009). Oral Reading Fluency as an Indicator of Reading Competence: A Theoretical, Empirical, and Historical Analysis. Scientific Studies of Reading, 5 (3), 239-256.

Gönen, M. ve Balat, G. U. (2002). Çocuk Kitaplarına Yeni Bir Yaklaşım: İnternette Resimli Çocuk Kitapları. Türk Kütüphaneciliği, 16 (2), $163-170$

Güneş, F. (2010). Öğrencilerde Ekran Okuma ve Ekranik Düşünme. Mustafa Kemal Üniversitesi Sosyal Bilimler Enstitüsü Dergisi, 7 (14), 1-20.

Gürcan, H. İ. (2004). Basılı ve Elektronik Yayımcılık Dersi Notları. Eskişehir: Anadolu Üniversitesi İletişim Bilimleri Fakültesi. 
Gürses, R. (1996). Okuma-Anlama Üzerine. Atatürk Kültür, Dil ve Tarih Yüksek Kurumu Bülteni, 9 (28), 98-103.

Landow, G. P. (1992). Hypertext: The Convergence Of Contemporary Critical Theory And Technology. Baltimore: John Hopkins University Press.

Maden, S. (2012). Ekran Okuma Türleri ve Türkçe Öğretmeni Adaylarının Ekran Okumaya Yönelik Görüşleri. Dil ve Edebiyat Eğitimi Dergisi, 1 (3), 1-16.

Oğuzkan, F. (1987). Okuma ve Dinleme Öğretimi (36-48). Türkçe Öğretimi. B. Özer (Ed.) Eskişehir: Anadolu Üniversitesi Yayınları.

Önder, I. (2011). e-Kitap ve Dünyada Elektronik Kitap Yayıncılığı. Türk Kütüphaneciliği, 25 (1), 97-105.

Rukancı, F. ve Anameriç ,H. (2003). "E-Kitap Teknolojisi ve Kullanımı Türk kütüphaneciliği, 17 (2): 147-166.

Yaman, H. ve Dağtaş, A (2013). Ekrandan Okumanın Okumaya Yönelik Tutuma Etkisi. Eğitimde Kuram ve Uygulama, 9 (4), 314-333. 